\title{
THE SPIRITUAL SENSES IN WESTERN SPIRITUALITY AND THE ANALYTIC PHILOSOPHY OF RELIGION
}

\author{
WILLIAM J. WAINWRIGHT
}

University of Wisconsin-Milwaukee

\begin{abstract}
The doctrine of the spiritual senses has played a significant role in the history of Roman Catholic and Eastern Orthodox spirituality. What has been largely unremarked is that the doctrine also played a significant role in classical Protestant thought, and that analogous concepts can be found in Indian theism. In spite of the doctrine's significance, however, the only analytic philosopher to consider it has been Nelson Pike. I will argue that his treatment is inadequate, show how the development of the doctrine in Puritan thought and spirituality fills a serious lacuna in Pike's treatment, and conclude with some suggestions as to where the discussion should go next. ${ }^{1}$
\end{abstract}

The concept of the spiritual senses has played a significant role in the history of Roman Catholic and Eastern Orthodox spirituality. It goes back at least as far as Origen, and figures prominently in the work of theologians as diverse as Bonaventure and Hans Urs von Balthasar. What is less well known (indeed almost totally unremarked) is that the doctrine also played an important role in some classical Protestant thought and spirituality. This is important for it suggests that the doctrine is (or at least should be) an important feature of Christian spiritual theology in general, and raises the question of whether similar concepts can be found in other theistic traditions. In spite of its importance, however, the concept has been almost totally neglected by analytic philosophers of religion. My essay will be divided into three parts. I will begin by

${ }^{1}$ Substantial portions of this article are taken from my "Jonathan Edwards and His Puritan Predecessors on the Spiritual Senses," in Sarah Coakley and Paul Gavrilyuk, eds., Spiritual Senses: The Perception of God in the History of Western Christian Theology. Cambridge: Cambridge University Press, forthcoming, and are reprinted with the kind permission of Cambridge University Press. 
examining the only treatment of the doctrine by an analytic philosopher that I am aware of (namely, Nelson Pike's). I will then show how the development of the doctrine of the spiritual senses in Puritan thought and spirituality fills a serious lacuna in Pike's treatment, and conclude by saying a few words about where I think the discussion should now go.

\section{PIKE AND THE SPIRITUAL SENSES}

The first two chapters of Nelson Pike's Mystic Union ${ }^{2}$ describe what are commonly regarded as the three principal forms of mystical prayer. The soul is directly aware of God in each but the degree of intimacy and the place of encounter differ. In the Prayer of Quiet, "God and the soul are close to each other" (Pike 5). In Full Union and (the culmination of) Rapture, however, they penetrate each other; God and the soul are held in mutual embrace. In the Prayer of Quiet and Full Union, the encounter between self and God takes place within the soul of the mystic. In Rapture, it transpires outside it. Quiet and Union thus differ with respect to the nature of the encounter but are alike with respect to its place or domain. In Full Union and Rapture, the nature of the encounter is the same but its place differs.

Chapter 3 discusses the doctrine of the spiritual senses which asserts that there are "five spiritual sense faculties" bearing "some likeness to the exterior senses" (Teresa of Avila) "by which God's presence in the various states of union is detected" (Pike 42). As Pike understands the doctrine, when the Christian mystic "claims to have 'seen' God, or to have 'smelled' or 'tasted" him, she "means to be affirming that God was detected in the encounter via actual sensations that are at least similar ... to the bodily perceptions usually identified with these terms" (Pike 44).

Sight, hearing and smell are distance senses. (I not only see things at a distance, I hear what is going on in the next room, and smell what is cooking in the kitchen when I am in the hall. Touch typically requires contact but I can feel the fire while standing at some distance from it.)

${ }^{2}$ Nelson Pike, Mystic Union: An Essay in the Phenomenology of Mysticism. Ithaca and London: Cornell University Press, 1992. The descriptive portions of Mystic Union rely heavily on the earlier work of Augustin Poulain and Albert Farges. 
In the Prayer of Quiet, God and the soul "are close but not so close as to preclude them coming closer . . . In Full Union and . . Rapture, God and the soul are in double embrace" (Pike 49). One would therefore expect that God would be detected by analogues of the distance senses in the Prayer of Quiet, and by analogues of taste and touch in Full Union and Rapture.

According to Pike this is exactly what we find. In the Prayer of Quiet, God is "heard," "smelled," and "touched" "in the restricted sense appropriate when the object perceived is still at some distance from the perceiver" (Pike 51). (Thus "Teresa says that the soul feels the heat coming from the 'interior depths"' [Pike 50)].) In Full Union and Rapture, God is touched and tasted.

There are anomalies, though. First, although sight is the paradigmatic distance sense, spiritual sight is seldom if ever associated with the Prayer of Quiet. It is frequently mentioned in connection with Full Union, ${ }^{4}$ however, and is especially associated with Rapture. Second, Pike thinks that the objects of spiritual hearing, touch, taste and smell bear some comparison (if only remote) to their ordinary counterparts. The object of spiritual taste, for example, is God's "sweetness," and the object of spiritual touch is his "caress" or "touch." The exception is spiritual sight whose typical objects are "power, will, justice, goodness," and the like, that is, properties whose ordinary counterparts cannot "be apprehended in simple acts of [visual] perception." It thus seems "that if we are to retain a parallel between spiritual sight and bodily sight, we shall have to introduce an analogue of 'bodily form' that can be spiritually seen" (Pike 60-61, my emphasis.) The trouble is that references to anything like this

${ }^{3}$ Pike quotes Ambrose who claims to "hear God's voice" in this state (the Prayer of Quiet) (Pike 51). Given Pike's schema, this is of course appropriate since hearing is a distance sense. But how often is "hearing" referred to at this stage? And when it is, how often does it refer to nothing more than a so-called "interior locution" (words or thoughts suddenly occurring to one) and not to a direct perception of God himself? (Question: Are the words or thoughts in these locutions perceived as coming from God himself. [Cf. My hearing my wife speak], or does one instead infer that they do, or simply form the conviction that they do. [Cf. I receive a letter from my wife without her signature or address.])

${ }^{4}$ But see Poulain's Graces of Interior Prayer (St. Louis: Herder, 1950), page 56, where he says that "as a rule, spiritual visual perceptions are absent in Full Union as they are in the Prayer of Quiet." 
seldom (if ever) occur in descriptions of the Prayer of Quiet, Full Union, or Rapture. ${ }^{5}$

The fact that the paradigmatic distance sense (sight) normally comes into play only in Rapture, in which God and the soul indwell one anotherr and are therefore not at a distance, and that there are no divine analogues of the objects of ordinary visual experience (color, shape, etc.) suggests to me that the doctrine of the spiritual senses imposes an overly rigid conceptual scheme on a comparatively unsystematic and fluid use of perceptual metaphors. A number of additional considerations reinforce this suspicion. Let me mention two of the most important.

(1) Pike claims that since God and the soul remain at some distance from one another in the Prayer of Quiet, the spiritual senses most appropriate to this form of union will be distance senses. Touch is involved but "only in the restricted sense appropriate when the object perceived is still at some distance from the perceiver." And Pike quotes Teresa who "says that the soul feels the heat coming from the 'interior depths," that is "(we can assume) . . . the most interior of the Seven Mansions." (The analogy is with, e.g." "feeling the heat of a stove which is at some distance from oneself" [Pike 50-51].) But while a feeling of interior warmth often is referred to in connection with the Prayer of Quiet, is it a feeling of something at a distance as Pike thinks, or instead just a less intense experience of the burning often felt in Full Union or Rapture? ${ }^{6}$

Augustin Poulain (whom Pike largely follows) implies that the answer is the latter. "That which constitutes the common basis of all the degrees of mystic union," including the Prayer of Quiet and Full Union "is that of the spiritual impression by which God makes known his presence . . . in the manner ... of something interior which penetrates the soul; it is a sensation of ... saturation, of immersion," and can be called "spiritual

${ }^{5}$ Though a careful examination of Christocentric mystics like Pierre de Berulle might force one to qualify this claim. See also the Shri Vaishnava theistic mystics' visions of the celestial body of Vishnu.

6 "Since God is an infinite fire of love, when therefore he is pleased to touch the soul with some severity, the heat of the soul rises to such a degree that the soul believes it is burned with a heat greater than any other in the world. For this reason it speaks of this touch as a burn." The heat in this case is not felt at a distance. Rather, the soul is not only "conscious of the burn, but it has itself become one burn of vehement fire." (John of the Cross, Living Flame of Love, trans. E. Allison Peers, Garden City, New York: Image Books, 1962, p. 59.) 
touch" (Poulain 90-91, my emphases). Because "it is a question ... here of a spiritual object which is not remote" but "manifests itself by uniting itself with us, dissolving into us as it were," the appropriate analogy is bodily touch (Poulain 94, my emphasis).

(2) Is the systematic use of all five perceptual terms typical of Christian mystics generally? Pike's discussion of the spiritual senses reflects his heavy reliance on John of the Cross and especially Teresa. The weight he assigns them isn't unreasonable given the fullness and clarity of their descriptions, their standing in the Roman Catholic community and their importance in the history of Christian mysticism. Their paradigmatic status in Pike's book also has important precedents in the work of Poulain, Albert Farges, Jacques Maritain and others. ${ }^{7}$ These mystics and theologians of mysticism aren't fully representative of the Christian mystical tradition as a whole, however.

Gregory of Nyssa, Pseudo-Dionysius and Maximus the Confessor "do not mention the concept of the 'spiritual senses' at all." Moreover, whereas Karl Rahner and others think we should speak of a doctrine of the spiritual senses "only when these partly figurative, partly literal expressions such as to touch God, the eyes of the heart, etc. are found" integrated in a "complete system" of the "five instruments ... involved in the spiritual perception of immaterial [religious] realities," this is much too restrictive.

Many ancient authorities who had important things to say about spiritual perception, did not develop anything amounting to a "complete system" or a body of doctrine of the spiritual senses. In fact most if not all patristic authors, including Origen whom Rahner regards as "the 'founding father' of the spiritual senses tradition, treat the matter casually rather than systematically" (Gavrilyuk, Introduction). Furthermore, there are significant differences between them. "Some ancient authorities" (as well as the $20^{\text {th }}$ century theologian Balthasar) "regard the spiritual senses as purified or transformed versions of the physical senses. Others [e.g., Origen] contrast [them] sharply, emphasizing that the physical senses need to be non-operational in order for the spiritual senses to function

\footnotetext{
${ }^{7}$ Poulain and Farges, too, stress the doctrine of the spiritual senses.

${ }^{8}$ Paul Gavrilyuk, "Introduction," Spiritual Senses: The Perception of God in the History of Western Christian Theology, op. cit.

${ }^{9}$ Karl Rahner, “The 'Spiritual Senses' according to Origen,” in Karl Rahner, Theological Investigations, vol. 16. New York: Seabury Press, 1979, p. 82.
} 
properly" (Gavrilyuk, Introduction). Nor is there a uniform list of the objects of the spiritual senses. "God, the eternal Word," the incarnate Word, "spiritual beings such as angels ..., transcendentals (the good, the true and the beautiful) and other divine attributes," and God's "presence in creation, in the sacraments, in the church, and in scripture" have all been suggested at one time or another (Gavrilyuk, Introduction). All this suggests that Christian accounts of the spiritual senses are too rich and too varied to be usefully reduced to any system.

Moreover, in spite of his insistence on the existence of five spiritual senses, Farges himself notes that not all of the spiritual senses are equally prominent ${ }^{10}$ in each mystic. Which ones play the leading role in any given case varies "according to the degree of union of each contemplative, and perhaps also with the temperament and character of each" (Farges 284). Take Bonaventure, for instance, who, according to Rahner, has the most fully developed version of the doctrine among the medievals. Sight and hearing relate to the intellect; smell, touch and taste to the will and affections. "The number five" is a bit "arbitrary," however, since "the sense of smell and hearing" are "more or less superfluous for [Bonaventure's] account of spiritual contemplation and its various levels" (Rahner 127). The important concepts for his analysis are spiritual sight, touch, and taste. Sight is a "simple vision (simplex contuitus)" whose object is "the immutable first truth" and "its eternal ideas which form the ultimate principles of all creation" (Rahner 116). Taste is "the appreciation by the affections" of the operations of grace in the soul, and is less perfect than feeling or touch which is identified with the ecstatic union of love. While "a direct clear vision of God" is essentially reserved for the afterlife, he can be directly apprehended by a loving will, and the term "touch" is appropriately used to indicate both the directness and the darkness ${ }^{11}$ of this affective union (Rahner 117, 127, my emphasis). ${ }^{12}$

${ }^{10}$ Or indeed always even evident.

${ }^{11}$ To the intellect.

${ }^{12}$ The accuracy of Rahner's interpretation of Bonaventure has been questioned. For example Mark McInroy argues that Bonaventure thinks that activities of the spiritual senses help make "one ready for ecstasy" but do "not function in ecstasy itself." (Mark McInroy, from his chapter on Bonaventure in Spiritual Senses: The Perception of God in Western Christian Theology, op cit.)

${ }^{13}$ The fact that Poulain, who insists on the existence of five distinct spiritual senses, assimilates (without explicitly identifying) "spiritual taste and a spiritual sense of smell" 
In my view, Rahner was correct in concluding that "if one assumes five different faculties which correspond analogically to the bodily powers of sensation, then one is going quite a long way beyond the empirical data [of mysticism]" (Rahner 133). The core of the analogy with bodily perception is the direct "experimental" awareness of a concrete (i.e., non-abstract) and present reality. Our "exterior senses" don't "perceive the essences of the objects around us, but only their presence and their physical effect upon our organs, and perceive these directly." Similarly, the "holy mystics" perceive the presence of God through his effects upon their souls. "Here on earth, the intelligence, except as regards itself and its operation, only apprehends directly the abstract and ideal; the senses alone are able to apprehend concrete and present reality, and" do so "directly." In an analogous way, the spiritual senses directly apprehend God's "concrete and present reality . . . . here is the same firmness and certainty of personal grip, the same ardent fullness of contact, of envelopment and penetration." ${ }^{14}$ Note that in this respect, the spiritual senses are not only analogous to the exterior senses, they are analogous to each other.

But to justify the claim that talk of distinct spiritual senses of seeing, hearing, smell, touch and taste is not merely "metaphorical and symbolic" but properly analogical, one would have to show that the sort of direct contact involved in each is properly distinct from that involved in the others and that the kind of contact involved in spiritual seeing, for example, is more like that involved in physical seeing than that involved in physical hearing, smell, touch, or taste. To the best of my knowledge no one has come close to doing this. ${ }^{15}$

to spiritual touch on the grounds that they too "are interpretations of certain shades of union" (Poulain 90) suggests that these categories are more open and fluid than he, Farges and Pike think. At the very least his remarks suggest that spiritual touch, taste, and smell aren't as sharply differentiated from one another as spiritual sight and spiritual hearing are from each other, and as both are from all three forms of the sensation of spiritual contiguity.

${ }^{14}$ Albert Farges, Mystical Phenomena, trans. S. P, Jacques from the $2^{\text {nd }}$ French edition. New York, Cincinnati, and Chicago: Benziger Bros., 1925, pp. 279-81.

${ }^{15}$ For all of his insistence on the existence of five spiritual senses, for example, Farges has not even tried to do this. Poulain does but his discussion is less than fully satisfactory. He says, for example, that spiritual sight is a "mode of [experimental] knowledge ... that we are instinctively led to compare ... with bodily sight," (Poulain 89) but he does not say 
In my opinion, then, the notion of the spiritual senses shouldn't be taken too literally. The metaphors may only have been designed to express intimacy (touch, taste), delight (sweetness, fragrance) and varying degrees of perceptual clarity. (Note that we could then explain why the paradigmatic distance sense, sight, isn't used in association with the Prayer of Quiet. Vision has been traditionally regarded as the most intellectual [and hence clearest] of the senses and one's awareness of God at this stage is relatively obscure.) One should consider the possibility, in other words, that expressions like "sight," "smell," taste" and so forth refer to only a few phenomenal qualities (the ones I have mentioned perhaps) each of which can be indifferently picked out by more than one perceptual metaphor. What is often analogical, however, and not merely metaphorical, is the comparison of spiritual perception in general to bodily perception in general. ${ }^{16}$

I conclude that Pike's analysis of the spiritual senses fails because it attempts to fit the language and experiences he discusses into a Procrustean bed which is ill suited to accommodate them. ${ }^{17}$ Its biggest lacuna, however, is its failure to address the relevant epistemological issues. Poulain and Farges do, however inadequately. Poulain says, for example, that we have "an experimental knowledge of the presence of God ... that is the result of an impression, a spiritual sensation of a certain kind" that bears "some resemblance" of an analogous kind to the sensations of the "bodily senses" (Poulain 88). And Farges says something similar. The theory both gesture at is developed most carefully by Jacques Maritain in Distinguish to Unite, or the Degrees of Knowledge. ${ }^{18}$ Since I have argued elsewhere that the theory in question is inadequate, ${ }^{19}$ I would like to turn

just how they are alike. "Spiritual hearing" is said to refer to the direct communication of God's thoughts to the mystic. But (as we have seen in note 13) spiritual smell, taste, and touch are more or less run together.

${ }^{16}$ And note that a number of Christian authors speak of spiritual perception in the singular without implying a specific likeness to any particular one of the bodily senses.

${ }^{17}$ In fairness to Pike, I should note that the fault in question primarily lies with the authors (especially Poulain and Farges) he is relying on.

${ }^{18}$ Jacques Maritain, Distinguish to Unite, or the Degrees of Knowledge, trans. from the $4^{\text {th }}$ French Edition under the supervision of Gerald B. Phelan. New York: Charles Scribner's Sons, 1959. See especially 247-470.

${ }^{19}$ William J. Wainwright, “Two Theories of Mysticism: Gilson and Maritain," The Modern Schoolman 52 (1975): 405-26. Reprinted in William J. Wainwright, Mysticism: 
to a couple of other models of spiritual sensation which at least at first glance might seem initially more promising.

\section{PURITANS AND THE SPIRITUAL SENSES}

That conversion involved the bestowal of a new spiritual sense was a Puritan commonplace. In what follows I shall argue that Puritans employ "a sense of the heart" in three different ways. It is often used for a feelingful conviction of gospel truths without any implication of direct or immediate cognitive contact with the divine. But its use more frequently reflects the conviction that a converted heart involves a direct or immediate awareness of God or "holy things." There were at least two models for this. The first is a "Platonic" model which construes the contact as the immediate intuition of a reason thought of as essentially possessing an affective dimension. The second model is sense perception.

While it is often difficult to determine just which of these three senses is intended, I shall argue that the Cambridge Platonist, John Smith

A Study of its Nature, Cognitive Value, and Moral Implications. Madison: University of Wisconsin Press, 1981, pp. 166-84. I continue to stand by the majority of the criticisms of Maritain that I made at that time. For example, Maritain (apparently) presupposes that all perceptual experience involves the presence of a quasi-sensible medium through which we apprehend that experience's object. He also appears to presuppose that perception can only occur when the perceived object causally acts upon the perceiver. Neither presupposition is self-evident. The first is clearly false if we grant that our immediate awareness of sense impressions and other mental states is a kind of perception. And if occasionalism is logically possible, then the second presupposition is false as well since, on that view, the presence of a physical object provides the occasion on which God produces appropriate sensory effects in the perceiver but isn't their cause. Even so, I am now less inclined to flatly dismiss Maritain's theory than I was in 1975 and 1981. His account of sense perception is at least as plausible as Edwards's Lockean account which I will discuss in section II, and if the Christian mystic does become experimentally aware of God's presence through the medium of the effects which God produces in her soul, it is plausible to identify those effects with the consciously experienced effects of infused charity. (For one thing, Christian mysticism is a love mysticism: love is the means of attaining union with God and the union itself is a form of love. For another, the higher stages of contemplation are attained by burying all creatures beneath a "cloud of forgetting." All that remains is the mystic's loving awareness of God. If this awareness involves a medium, it seems that we must identify it with love since love is the only thing other than the awareness itself which hasn't been excluded from her consciousness). 
(1616-1652), rather clearly intended the second (a Platonic affect-laden intellectual intuition) while the great American theologian, Jonathan Edwards (1703-1758), intended the third (a direct cognition modeled on sense perception).

The Puritan's talk of spiritual senses should be placed in the context of devotional practices that were strikingly similar to those of contemporary sixteenth and seventeenth century Roman Catholics. They "knew and used classic Catholic devotional works." Among "the most popular, judging from the number of editions, were the works of St. Augustine, St. Bernard of Clairvaux," and "Thomas a Kempis's The Imitation of Christ ... To a large extent, the Puritan devotional literature that blossomed in the early seventeenth century was modeled on earlier Roman Catholic devotional literature." "Continuity" also "existed in the area of techniques ... Most important was the use of the imagination and the senses in the exercise known as composition of place," i.e., placing oneself within the scenes of the salvation story on which one is meditating. ${ }^{20}$

For Richard Baxter (1615-1691), meditation involved (1) using the sensory images of scripture to visualize (as well as to imaginatively hear, smell, and touch) divine things while at the same time recognizing the images' inadequacy, together with (2) a single minded concentration on the excellences of heaven or other objects of meditation, with the penultimate aim of eliciting and strengthening holy thoughts, desires and feelings, and (like other Puritans) the ultimate aim of achieving "union with Christ, a union that was [typically] expressed in mystically erotic imagery from the Song of Songs and Jesus' parable of the ten virgins" (HS 189). ${ }^{21}$

Regular times were set aside for meditation in a place "free from company and noise," and from other distractions (HS 163). Baxter, for instance, admonishes his reader to "Get thy heart as clear from the world as thou canst. Wholly lay by the thoughts of thy business, troubles, enjoyments, and everything that may take up any room in the soul. Get it as empty as thou possibly canst, that it may be the more capable of being

${ }^{20}$ Charles E. Hambrick-Stowe, The Practice of Piety: Puritan Devotional Disciplines in Seventeenth Century New England. Chapel Hill: University of North Carolina Press, 1982, pp. 28-33, 36. Henceforth HS.

${ }^{21}$ The five foolish virgins were sometimes interpreted in the wider tradition as the five bodily senses, and the five wise virgins as the five spiritual senses. 
filled with God ... say to thy worldly business and thoughts, as Christ to his disciples, 'Sit ye here while I go and pray yonder." 22

It is difficult to overemphasize the importance which Puritans placed on these spiritual practices. "Regular secret prayer" was regarded as "the primary and most necessary means" of grace. John Cotton (1584-1652), for example, argued that "the end of preaching" was that one "may learn to pray" (HS 177). Richard Baxter urged that meditation on heaven, i.e., on "the ravishing glory of saints, and the unspeakable excellencies of the God of glory, and the beams that stream from the face of his son" is the "duty by which all other duties are improved, and by which the soul digests truth for its nourishment and comfort." Meditation of this sort involves "the acting of all the powers of the soul," the will and the affections as well as the understanding. For "what the better had we been for odoriferous flowers, if we had no smell . . or what pleasure should we have found in meats and drinks, without the sense of taste? So what good could all the glory of heaven have done us, or what pleasure should we have had in the perfection of God himself, if we had been without the affections of love and joy?" (Baxter xiii, pp. 1-2).

Prayer brings us to communion with God. Thomas Shepard (16051649) said, "I have seen God by reason and never been amazed at God . .. I have seen God himself [in prayer] and have been ravished to behold him" (HS 179). Cotton Mather (1663-1728) spoke of being "inexpressibly irradiated from on high," of being "exceedingly ravished," "raised up into Heaven," of "delights and raptures," and reported an experience in which he was transported "into the Suburbs of Heaven" where he was filled with a "Joy unspeakable and Full of glory. I cannot utter, I may not utter, the Communications of Heaven, whereto I have been this Day admitted: but this I will say, I have tasted that the Lord is gracious" (HS 285f).

But while talk of spiritual senses is common, even pervasive, it is unclear how literally it was intended. Sometimes our authors' language rather strongly suggests that the most appropriate model of spiritual perception is ordinary sense knowledge. Thus Richard Sibbes (15771635) asserts that "the spiritual life of a Christian is furnished with spiritual senses. He hath a spiritual eye and a spiritual taste to relish

${ }^{22}$ Richard Baxter, The Saint's Everlasting Rest (abridged), New York: American Tract Society, 1850?; reproduced online by the Christian Classics Ethereal Library, 1999, chapter xiii, p. 6. Henceforth Baxter. 
spiritual things, and a spiritual ear to judge of holy things, and a spiritual feeling. As everyday life, so this excellent life hath senses and motions suitable to it." ${ }^{23}$ Or consider the Puritan mystic Francis Rous (15791659): "After we have tasted those heavenly things . . . from this taste there ariseth a new, but a true, lively, and experimental knowledge of the things so tasted ... For even in natural fruits there are certain relishes ... which nothing but the taste itself can truly represent and shew to us. The West-Indian Piney [pineapple] cannot be so expressed in words, even by him that hath tasted it, that he can deliver over the true shape and character of that taste to another that hath not tasted it." ${ }^{24}$

John Owen (1616-1683) also employs the language of the senses. But when placed in the context of his thought as a whole, his talk of the spiritual senses is arguably a metaphor for an affect-laden intellectual insight or intuition: "the true nature of saving illumination consists in this, that it gives the mind such a direct intuitive insight and prospect into spiritual things as that, in their own spiritual nature, they suit, please and satisfy it, so that it is transformed into them, cast in the mould of them, and rests in them" (Walton 202).

More detailed models of these two ways of understanding spiritual perception are developed by Jonathan Edwards and John Smith, respectively. Consider, first, Edwards.

Because their hearts have been regenerated by the indwelling of the Holy Spirit, the saints love "being in general" (i.e., God and the things that depend on him). Their love of being in general is the basis of a new "spiritual sense" whose "immediate object" is "the beauty of holiness"a "new simple idea" that can't "be produced by exalting, varying or compounding" ideas "which they had before," and that truly "represents" divine reality. ${ }^{25}$

${ }^{23}$ Brad Walton, Jonathan Edwards, Religious Affections, and the Puritan Analysis of True Piety, Spiritual Sensation, and Heart Religion. Lewiston, Queenston, Lampeter: The Edward Mellon Press, 2002, p. 198. Henceforth Walton.

${ }^{24}$ Quoted in Geoffrey Nuttall, The Holy Spirit in Puritan Faith and Experience. Chicago and London: University of Chicago Press, 1992 (originally published by Basil Blackwell, 1946, $2^{\text {nd }}$ ed., 1947), p. 139. Henceforth Nuttall.

${ }^{25}$ Jonathan Edwards, Treatise on the Religious Affections, 1746: The Nature of True Virtue, 1765, in The Works of Jonathan Edwards. New Haven: Yale University Press, 19572006., vol. 2, pp. 205, 260; vol. 8, p. 622. Henceforth RA and TV, respectively. 
Edwards sometimes identified true beauty with the pleasure that holy things evoke in people with spiritual "frames" or "tempers" or with the tendency they have to evoke it. At other times he variously identified it with what he called the "consent of being to being," or the "love of being in general," or "true benevolence" or holiness. His view on the whole appears to be this. True beauty is identical with benevolence or agreement ("consent") in somewhat the same way in which water is identical with $\mathrm{H} 2 \mathrm{O}$ or heat with molecular motion. But benevolence is also the objective basis of a dispositional property, namely, a tendency to produce a new simple idea in the savingly converted. This idea is a delight or pleasure in being's consent to being which somehow "represents" or is a "perception" of it. Edwards's account of true beauty thus resembles contemporary Lockean accounts of color or extension. Spiritual delight is a simple idea or sensation like our ideas of color or extension. The dispositional property is a power objects have to produce these ideas in our understandings. Benevolence or the consent of being to being is the objective configuration underlying this power and corresponds to the microstructure of bodies that underlies their tendency to excite ideas of color or extension in minds like ours. Like simple ideas of redness, say, or extension, the new spiritual sensation "represents" or is a "perception" of its object. Just as "red" or "extension" can refer to the idea, the power, or the physical configuration that is the basis of this power, so "true beauty" can refer to the spiritual sensation, to the relevant dispositional property, or to true benevolence.

Edwards called the new mode of spiritual understanding a "sense" because the apprehension of spiritual beauty is (1) non-inferential and (2) involuntary, and Edwards, like Francis Hutcheson, associated sensation with immediacy and passivity. (3) It involves relish or delight, and Edwards followed Locke and Hutcheson in thinking that, like a feeling of tactual pressure or an impression of redness, being pleased or pained is a kind of sensation or perception. Finally, (4) the new mode of understanding is the source of a new simple idea, and Edwards shared Locke's and Hutcheson's conviction that simple ideas come "from experience."

John Smith's model of spiritual perception is rather different. He is no more averse to employing the language of the spiritual senses than Owen. He speaks, for example, of "the senses of the soul," with Plotinus 
of an "intellectual touch" of God, and says that "the soul it self hath its sense as well as the body." "There is," he says, "an inward sweetness and deliciousness in divine truth which no sensual mind can taste or relish.. . Divinity is not so well perceived by subtle wit ... as by a purified sense, as Plotinus phraseth it" (SD 15).

Smith's spiritual sensation is best thought of as an intellectual intuition, however, an act of "that reason that is within us" (SD 15). "We must shut the eyes of sense, and open that brighter eye of the understanding, that other eye of the soul, as the philosopher calls our intellectual faculty... the light of the divine world will then begin to fall upon us ... and in God's own light shall we behold him. The fruit of this knowledge will be sweet to our taste, and pleasant to our palates ... When reason once is raised by the mighty force of the Divine Spirit into a converse with God, it is turned into sense ... [W] hereas before we conversed with him only. . . with our discursive faculty . . . combating with difficulties, and sharp contests of divers opinions, and laboring ... in its deductions of one thing from another; we shall then fasten our minds on him ... with a serene understanding . . . such an intellectual calmness and serenity, as will present us with a blissful, steady and invariable sight of him." What "before was only faith . . . now becomes vision" (SD 15-16, my emphases).

Yet if Smith's "spiritual sensation" is best thought of as an intellectual intuition or perception, why employ the language of the bodily senses? Partly because it was traditional. But primarily, I think, because our familiar senses are apt metaphors for the intuition's directness or immediacy and for its affective overtones.

\section{PROSPECTS FOR THE TWO PURITAN MODELS OF SPIRITUAL PERCEPTION}

How should Edwards's and Smith's models be assessed? Note first that both are models of spiritual perception as such, not of spiritual seeing or hearing or touch or tasting or smell, in particular. I shall argue

${ }^{26}$ John Smith, Select Discourses, London: Printed by F. Flesher for W. Morden, 1660; New York and London: Garland, 1978 (reprint), pp. 5, 3. 
that Edwards's model, while more fully developed than Smith's, is less adequate than his.

In the first place, although it is clear why Edwards speaks of the new spiritual cognition as a perception or sensation, it is not clear that he should have done so. His first two reasons for construing it on the model of bodily sensation are far from conclusive. Our sensations (and the beliefs directly based on them) appear involuntary and immediate, but so too does our recognition of the fact that $2+2=4$. Passivity and immediacy aren't peculiar to ideas derived from (internal or external) sensation.

The other two considerations carry more weight. Locke and Hutcheson identified reason with reasoning. Reason is sharply distinguished from the will and its affections and from the senses. Its sole function is to manipulate ideas received from other sources. Edwards sometimes indicates that he shares these views. Reason does not have an affective dimension and is not the source of new simple ideas. The cognition of true beauty, on the other hand, has an affective dimension since it involves relish or delight, and its object is a new simple idea. If these considerations are sound, then it seems that spiritual cognition should be construed as a kind of sensation or perception.

Edwards's account of spiritual perception is subject to some of the same difficulties as Locke's account of sense perception. ${ }^{27}$ But it is also subject to a difficulty of its own. If I am right, the idea of true beauty is both a kind of delight or relish and an apparent cognition. Can something be both? It isn't sufficient to argue that perceptions of objectively real value properties can be inherently affective (and thus pleasurable or painful), for Edwards doesn't think of pleasure and pain in this way. Pleasures and pains in his (and Locke's and Hutcheson's) view aren't qualities or affective dimensions of more complex experiences. They are discrete internal sensations. But if pleasure is a kind of internal thrill or delight, how can it also be a true "representation" of something existing "without" (TV 622-23)? Ordinary pleasures and pains differ from visual or auditory impressions in lacking what Berkeley called "outness;" they don't seem to point beyond themselves. Either spiritual pleasure is radically unlike ordinary pleasure in this respect or it isn't an apparent cognition.

${ }^{27}$ It isn't clear that the mind's immediate objects are ideas, how these ideas represent or resemble their objects, and so on. 
Edwards implicitly addresses this issue by attempting to show that "the frame of mind, or inward sense... whereby the mind is disposed to" relish true benevolence for its spiritual beauty agrees "with the necessary nature of things" (TV 620). The "frame of mind" in question, however, is benevolence itself. Hence, if we can show that benevolence has a foundation in the nature of things, we can conclude that the spiritual sense, too, is aligned with reality. Edwards has several arguments to show that it does, ${ }^{28}$ but his most interesting is perhaps this.

In Edwards's view, "the Spirit of God . . . communicates and exerts itself in the soul [of the saints] in those acts which are its [God's] proper, natural, and essential acts in itself ad intra." "The act which is [the Deity's] nature, and wherein its being consists in . . is divine love," however. ${ }^{29}$ This explains how the saints' benevolence is grounded in the nature of things. If the love of the saints just is God's love, and God's love is the Holy Spirit, then the benevolence of the saints is an act of the infinite and omnipotent benevolence which lies at the heart of reality. ${ }^{30}$

Another problem isn't so easily overcome, though. That spiritual cognition is best thought of as a kind of sensation or perception on the model of bodily seeing, hearing, tasting and the like, seems inconsistent with other aspects of Edwards's position. A number of Hutcheson's critics took exception to his moral sense theory because they believed that (1) at least some moral propositions are necessarily true, and that (2) necessary truths are discerned by reason. ${ }^{31}$ Hutcheson maintained that the moral sense grasps the goodness of benevolent actions and dispositions, that is, perceives that benevolence is (morally) good. His critics objected that "Benevolence is good" is necessarily true, and that

${ }^{28}$ Four of them are offered in the final chapter of The Nature of True Virtue. For a discussion of them, see my Reason and the Heart, Ithaca, NY: Cornell University Press, 1995, pp. 34-38.

${ }^{29}$ Jonathan Edwards, “Miscellany 471," in The Works of Jonathan Edwards, vol. 13. New Haven: Yale University Press, 1994, p. 513.

${ }^{30}$ While Edwards normally insists on identity or something close to it, a sufficiently close resemblance relation might itself be enough to explain why true benevolence is grounded in the nature of things. If the saints' loving actions and temper mirror God's action and temper, then their benevolence is appropriately related to objective reality because it resembles or is an image of it. Nature's activity on Edwards's occasionalist view is really God's activity. Love is thus "natural" because it imitates the action of nature itself.

${ }^{31}$ See, for example, the correspondence between Hutcheson and Gilbert Burnet. 
necessary truths are apprehended by reason, not sense. It is therefore significant that Edwards, too, apparently believed that basic moral truths are necessary. ${ }^{32}$ Nor is he likely to have thought that the connection between benevolent actions and dispositions and spiritual beauty is only contingent - that holiness or benevolence might not have been truly beautiful. But if "holiness is beautiful" is necessarily true, Edwards seems committed to the implausible view that our knowledge of at least some necessary truths is derived from a sense, i.e., that some necessary truths are perceived by a kind of sensation. It is important to note that the problem here does not arise from Edwards's use of a peculiarly neoLockean model of bodily perception. Because the physical senses can't apprehend necessary truths, it would arise from any use of models of bodily perception. ${ }^{33}$

One could avoid this problem as well as the one raised earlier by interpreting spiritual cognition as an intellectual intuition with affective

${ }^{32}$ Edwards clearly thought that at least some moral truths are necessary. See his Freedom of the Will (The Works of Jonathan Edwards, vol. 1, New Haven: Yale University Press, 1957), p. 153. His example is, "It is ... fit and suitable, that men should do to others, as they would that they should do to them." It is worth observing that Locke, too, thought that basic moral truths are necessary.

${ }^{33}$ Including those of Poulain, Farges and Maritain. One might protest that the objection cuts against Maritain only if "experimental knowledge" of God, on his view, incorporates a belief in necessary truths, and that it does so is doubtful. For, in the first place, it isn't clear that the experimental knowledge of God incorporates propositional knowing, and even if it does, it is far from obvious that the propositions known are necessary truths. This doubt is reinforced by the fact that the medium through which the mystic apprehends God, on Maritain's view, (namely, the consciously experienced effects of infused charity) are more closely analogous to the sensory effects of physical objects on our bodily senses than to the concepts through which we grasp abstract objects and which we incorporate in propositions. But while the passive reception of the sensory effects of physical objects may be a necessary condition of perceptual knowledge, it isn't sufficient. For example, perceptual knowledge of the table I am looking at requires my recognition that the object I am experiencing is a table. Similarly here. The knowledge in question is an experimental knowledge of God only if the subject is at least implicitly aware that "the Divine Reality" is "present within us" in virtue of its action upon the soul (Maritain, op. cit., p. 272). The mystic's experience thus does incorporate propositional knowledge. Moreover, if the propositions known entail that God exists (as they surely must for Maritain, since "God is present in my soul" entails "God exists"), and "God exists" is a necessary truth as the tradition arguably maintains, then Maritain's account of the mystic's experimental knowledge of God is exposed to the same sort of objection as Edwards's. 
overtones in the manner of Smith. A view like Smith's sidesteps the two most pressing problems confronting Edwards - how a feeling of delight can also be an apparent cognition, and how a necessary truth can be grasped by a kind of sensation. It sidesteps them because (1) on Smith's view, the "sensation" or "feeling" isn't the cognition itself but, rather, its accompaniment or (better) its affective dimension or resonance, and because (2) there is no mystery ${ }^{34}$ in necessary truths and "platonic" entities such as numbers, universals, archetypes and values, being objects of intellectual intuition.

But while I find Smith's model more promising, it clearly needs further development. If I am right, Smith employed the language of the spiritual senses because it was familiar and because ordinary sense perception provides an apt metaphor for the intuition's directness or immediacy and affective overtones. Other analogies are at least as apt, however, and should be explored further. The spiritual cognition's directness, for example, is strikingly similar to our immediate recognition of the prima facie rightness of an instance of justice or kindness on a view like W. D. Ross's, or our immediate acquaintance with numbers, universals, values and other so-called "platonic" entities on the views of a number of contemporary epistemologists. Nor are intellectual intuitions always affectless. Kant's respect for the moral law is the affective resonance of the recognition of its obligatoriness in rational beings with inclinations, while classical Platonists thought that reason itself has an affective dimension. Knowing the good involves loving it, delighting in it and putting it into practice - a view which Smith shared. ("Intellectual life, as [the Platonists] phrase it" is a non-discursive "knowledge ... [that] is always pregnant with divine virtue, which ariseth out of an happy union of souls with God, and is nothing else but a living imitation of a Godlike perfection drawn out by a strong fervent love of it. This divine knowledge ... makes us amorous of Divine beauty ... and this divine love and purity, reciprocally exalts divine knowledge" [SD 20].)

The immediate task for those interested in Smith's model of spiritual perception is thus a close examination of the classical Platonists' account of our knowledge of the forms, the Good and the One, and contemporary literature on the epistemology of intuition in (e.g.) logic and mathematics,

\footnotetext{
${ }^{34}$ Or at least, less mystery.
} 
ethics and philosophy. If one or more of these accounts is defensible, so too, I suspect, will be Smith's.

It may also be useful to examine similar conceptions in other theistic traditions such as Vaishnavism. ${ }^{35}$ Nammalvar sings of the Lord swallowing him, for example: "The Lord abides in [his] heart, and when it melts, swallows it." 36 "He who seized me came, the other day/ and ate my life./ Day after day, he comes, and devours me so fully./ Was that the day that I became his servant?" (9.6.8). Or again, "He ate my life fully and was filled./ He became all worlds and all life/ ... and he then became just for me, honey, milk, syrup, [and] nectar" (10.7.2) (CN 168f., 172f.).

But then, as the last line implies, the poet also swallows the Lord "who is beyond all senses and thought" (CN 160). He "entered my heart filling it./ I have obtained my love ["and contain him"]. I ate the nectar, and rejoiced" (10.8.6) (CN 173). "The Tamil word for 'nectar' . . is amutu (from the Sanskrit amrta, the substance that gives immortality) and the phrase 'nectar of the mouth' is used to mean kissing." Thus the poet, speaking as one of the god's female lovers (gopis) exclaims "Embrace my beautiful breasts/ with the fragrance of the wild jasmine/ on your radiant chest./ Give me the nectar of your mouth" (10.3.5). "Amutu also means 'food' and enjoyment" (CN 170-71). The upshot is that the poet and the Lord include one another. And as in the West, this mutual union or embrace between God and his devotee is expressed by images of taste, touch and smell. Another interesting example is the following.

The Gaudiya Vaishnavas who identify ultimate reality with Krishna ${ }^{37}$ believe it is revealed "in the form of a cosmic drama," known as the Krishna-lila. The heart of this drama is the love play between Krishna and the female cowherds (gopis) whose story is told in the Bhagavata Purana. The purpose of this revelation "is to provide humans with a model of, and for, perfection." ${ }^{38}$ This model centrally includes passion which Jiva

${ }^{35}$ Vaishnavas are monotheists, and describe God (Vishnu) as omniscient, omnipotent, and all loving.

${ }^{36}$ John Carman and Vasudha Narayanan, The Tamil Veda: Pillan's Interpretation of the Tiruvaymoli. Chicago and London: University of Chicago Press, 1989, p. 166. Henceforth $\mathrm{CN}$.

${ }^{37}$ For many Vaishnavas, Krishna is the principle avatara („descent” or „bodily” manifestation) of Vishnu.

${ }^{38}$ David L. Haberman, Action as a Way of Salvation: A Study of Raganuga Bhakti 
Gosvamin (fl. 1555-1600) defines as an instance of "that love which consists of an immense desire of a subject for union with the object of its desire," and which Rupa (fl. 1495-1550) claims provides the "highest access" to Krishna (Haberman 70).

The devotee internalizes the stories of Krishna by identifying with one of Krishna's companions, thereby attempting to transform his or her identity. The anubhavas are the "spontaneous and natural [external] expressions" of the characters' "inner emotions." By imitating, or taking on, the actions of one of the characters in the story, the devotee hopes to "obtain the salvific emotions of that character and [thus] come to inhabit the world [namely, Vraja] in which that character resides" (Haberman 69f).

To explain more fully: According to Gaudiya Vaishnavism, "the body $\ldots$ is the house of the soul or self (atman). Identity is what locates the self in a particular body which resides in a particular world. To participate in the world of Vraja," for example, "one must occupy a body located in that world. And to accomplish this one must develop an identity which connects one to such a body .. . Salvation in Gaudiya Vaishnavism" should therefore "be seen as the shift of identity from the external ... body" of ordinary life "to [one's] true body which is similar" to that of the exemplary character whose actions one is imitating (Haberman 73).

Since "amorous emotion [madhura-bhava) ... contains the essence of all other emotions," it "is perfectly represented by ... the female lovers of Krishna, . . the gopis of Vraja." Imitation of amorous bhakti (i.e., loving devotion) is thus modeled on the gopis. It is "divided into two types." The first involves "the desire for direct... enjoyment" and sexual union "with Krishna" (my emphasis), and therefore consists in identifying oneself with one of Krishna's female lovers. The second involves a "desire to share in the special emotions" of one of the female companions or attendants of his lovers (usually a companion of Radha, Krishna's favorite gopi), and thus to vicariously share in the latter's amorous passion (Haberman 81-85).

What particularly interests me is that salvation, on this view, involves the acquisition of a "perfected body" whose characteristics mirror, while transcending and transforming, those of one's "earthly" body. If

Sadhana. Oxford and New York: Oxford University Press, 1988, p. 45. Henceforth Haberman. 
one's perfected body does mirror one's earthly body, however, it must possess analogues of our physical senses. What one would like, therefore, is a more detailed account of just how these analogues of our physical senses function, and the ways in which they resemble and differ from the latter - models that play a role similar to those of Maritain or Jonathan Edwards or John Smith, for example. Doing so would potentially shed further light on the tradition of the spiritual senses which has been the subject of this article. 